$\therefore \therefore$
$\therefore$

$\quad 051011$

\section{PB.229085}

HEALTH HAZARD EVALUATION REPORT 72-14-3

USCO SERVICES, INC.

South Expressway and Perimeter Highway

Forest Park, Georgia 30050

Report Prepared By:

Kenneth J. Kronovecer

Industrial Hygienist

Region IV, Atlanta, Georgia

Jerome P. Flesch

Chief, Hazard Evaluation Services Branch

Apri1. 1972

U. S. DEPARTNENT OF HEALTH, EDUCATION, AND WELFARE

NATIONAL INSTITUTE FOR OCCUPATIONAL SAFETY AND HEALTH

ATIANTA, GEORGIA 30323 
U. S. DEPARTMENT OF HEALTH, EDUCATION, AND WELFARE NATIONAL INSTITUTE FOR OCCUPATIONAL SAFETY AND HEALTH Atlanta, Georgla 30323

\author{
HEALTH HAZARD EVALUATION REPORT 72-14 \\ USCO SERVICES, INC. \\ South Expressway and Perimeter Highway \\ Forest Park, Georgia 30050 \\ April 1972
}

\title{
SUMMARY DETERMTNATION
}

Section $20(a)(6)$ of the Occupational Safety and Health Act of 1970 , 29 U.S.C. 669 (a) (6), authorizes the Secretary of Health, Education, and Welfare, following a written request by any employer or authorized representative of employees, to determine whether any substance normally found in the place of employment has potentially toxic effects in such concentrations as used or found.

The National Institute for Occupational Safety and Health received such a request regarding exposure to carbon black dust in and near the carbon black storage area at the USCO Services, Inc. Warehouse, South Expressway and Perimeter Highway, Forest Park, Georgia 30050.

Airborne dust levels in the carbon black storage area on April 18-19, 1972 were well below appropriate Threshold Limit Values. On the basis of the alr sample results and other observations, it is concluded that recommendations as regards control of the alleged hazard, are unnecessary.

Coples of this sumary determination, as well as the survey report are available from the National Institute for Occupational Safety. and Health. Copies of both have been sent to:

1) USCo Services, Atlanta, Goorgia

2) Authorized Representative of Employees

3) U. S. Department of Labor

For purposes of informing "affected employees", the employer will either (1) "post" the Sumary Determination in a prominent place near where affected employees work or (2) provide a copy of the determination to each affected employee. Additionally, the employer shall make a copy of the Sumary Determination available to any affected employee upon request. 


\section{INTRODUCTION}

Section 20(a)(6) of the Occupational Safety and Health Act of 1970 , 29 U. S. C. 669 (a) (6), authorizes the Secretary of Health, Education, and Welfare, following a written request by any employer or authorized representative of employees, to determine whether any substance normally found in the place of employment has potentlally toxic effects in such concentrations as used or found.

The National Institute for Occupational Safety and Health recelved such a request regarding exposure to carbon black dust in and near the carbon black storage area at the usco Services, Inc. Warehouse, South Expressway and Perimeter Highway, Forest Park, Georgla 30050.

On March 23, 1972 a walk-thru survey was made at the carbon black storage area by $\mathrm{Mr}$. Kenneth Kronoveter of the klational Institute for Occupational Safety and Eealth. Accompanying Mr. Kronoveter on the walk-thru survey were Warehouse Manager, and / Branch Manager, Union Steward. Prior to the walk-thru, Part I of the National Survelllance Network Questionnaire was fillad out with the assistance of

On Apri1 18 and 19, 1972 air sampling for carbon black dust was conducted in and near the carbon black storage area. This air sampling was conducted by Mr. Henry Ramos and Mr. Kenneth Kronoveter of the National Institute for Occupational Safety and Health. During the course of the two days a number of discussions were held with union as well as management representatives.

\section{DESCRIPTION OF PLANT OPERATIONS}

USCO Services, Inc., a division of UniRoyal, Ime. operates a series of commercial warehouses in a number of cities. As physical distribution specialists, they offer a variety of warehousing services to users of the system.

The Atlanta warehouse includes some 200,000 square feet of warehouse floor space with the carbon black storage area cering about 10,000 square feet. Approximately 130 people are emples at the facility on a two shift per day basis. Of these 130 indlyduals, about 70 work in the warehouse proper with one man usually spending three to four hours per day in the carbon black area.

The work in the carbon black area consists mostiy of loading and unloading 25 pound bags and 50 pound boxes in litized pallet form although quite often the pallets are broken dom to provide for smaller 
shipments. At the time of the survey, although a man was not working specifically in the carbon black area, there was enough traffic through the area such that conditions were probably not much different from those of a normal workday.

In general, the area was quite clean considering the material that is handled. It was Indicated that when a spill of carbon occurs a maintenance crew is called to clean up the spllled carbon in order to preclude the forklifts and foot traffic from tracking the carbon black throughout the warehouse. Some carbon black spillage was observed where the pallets are located.

\section{HAZARD INFORMATION}

The Occupational Health Standard for carbon black as promulgated by the U. S. Department of Labor, Federal Reglster, Volume 36, No. 157, August 13, 1971, paragraph 1910.93 is 3.5 milligrams of carbon black per cubic meter of air $\left(\mathrm{mg} / \mathrm{m}^{3}\right)$. An employees' exposure to this material in any eight hour work shift of a 40 hour work week shall not exceed the eight hour time-weighted average limit of $\mathrm{mg} / \mathrm{m}^{3}$.

Since the U. S. Department of Labor has adopted the American Conference of Governmental Industrial Hygienists' Threshold Limit Values as a portion of its standards, a copy of the documentation for carbon black is Included as Appendix A.

\section{EVALUATION METHODS AND RESULTS}

All dust samples were general room aix samples collected at the sampling points shown on Figure 1 . These samples were collected on $37 \mathrm{~mm}$ diameter vinyl metricel filters and were analysed gravimetrically. In all cases the sample was collected with the filter facing down and with the pump operating at 1.7 liters per minute. The results were rounded off to the closest tenth (0.1) of a milligram per cubic meter and are presented in Table 1 . As shown on Table 1 , all of the air samples yielded results which indicate airborne concentrations of dust well below the U. S. Department of Labor standards. Although it is not correct to assume that all of the dust collected was carbon black for the purposes of this study it is of little matter.

\section{DISCUSSION AND RECOMMENDATIONS}

The air sample results are such that recomendations directed towards the amelioration of afrborne dust concentrations in the carbon black 
storage area are not necessary. It was learned that the Company provides U. S. Bureau of Mines approved respirators for the workers to use while they are unloading boxcars. It is recomended that the company continue this practice. 
FIGURE $1-5-$

SAMPLING LOCATIONS - CHARCOAL STORAGE AREA
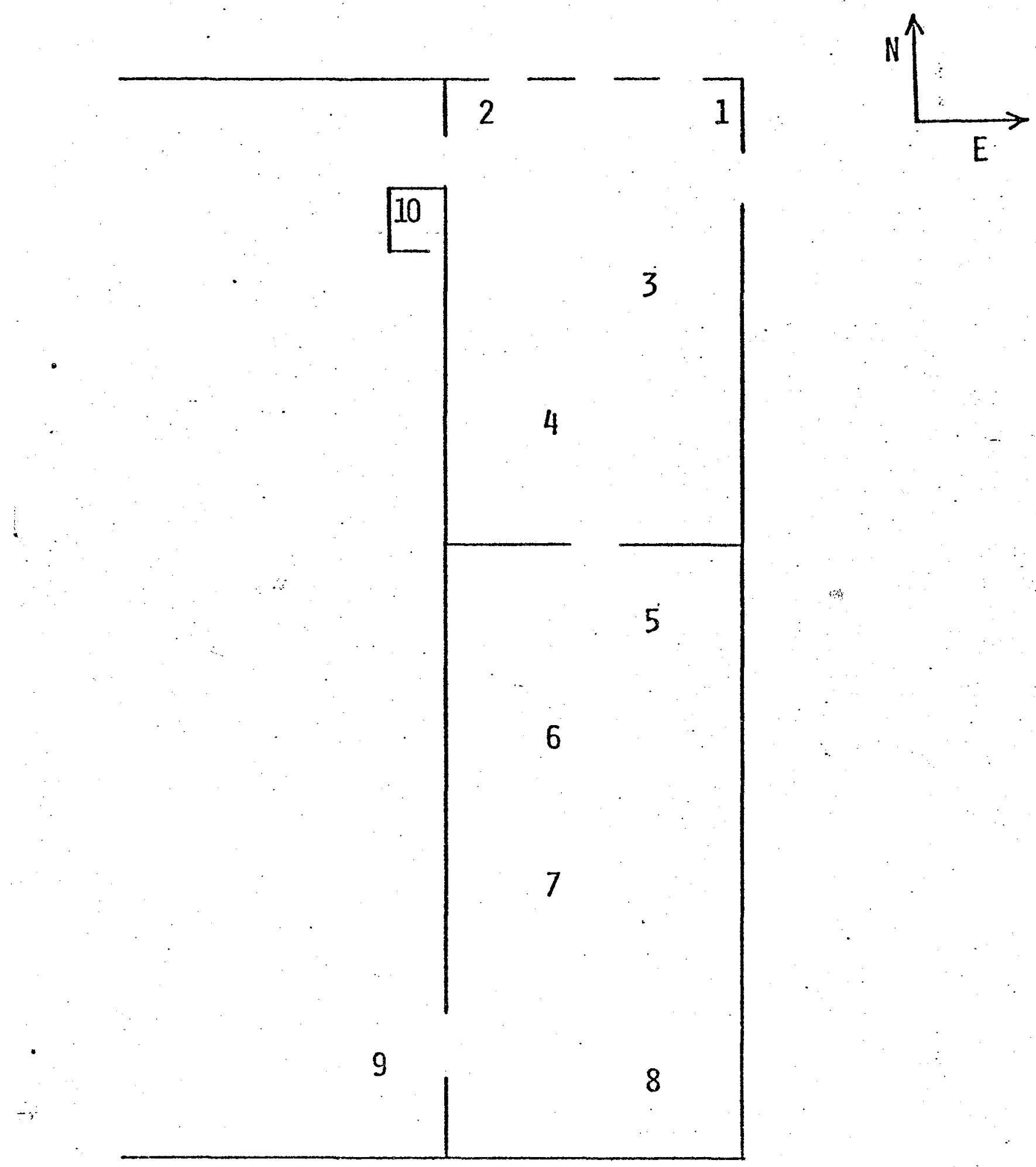
TABLE 1

AIRBORNE DUST CONCENTRATIONS

\begin{tabular}{|c|c|c|c|c|c|}
\hline Date & Sample Time & Location & & & $\begin{array}{c}\begin{array}{c}\text { Concentration } \\
\left(\mathrm{mg} / \mathrm{m}^{3}\right)\end{array} \\
\end{array}$ \\
\hline $4 / 18 / 72$ & $0900-1530$ & Sampling & Point & $\$ 1$ & 0.0 \\
\hline$"$ & $0907-1533$ & $n$ & $"$ & 2 & .4 \\
\hline$"$ & $0908-1534$ & is & $"$ & 3 & .1 \\
\hline$"$ & $0909-1537$ & $"$ & $"$ & 4 & .0 \\
\hline$"$ & $0910-1538$ & $"$ & $"$ & 5 & .1 \\
\hline$"$ & $0910-1539$ & $"$ & $"$ & 6 & .6 \\
\hline$"$ & $0911-1540$ & $"$ & $"$ & 7 & .3 \\
\hline$"$ & $0914-1540$ & $"$ & $"$ & 8 & .6 \\
\hline " & $0915-1542$ & $n$ & $"$ & 9 & .2 \\
\hline " & $0916-1543$ & $"$ & $"$ & 10 & .2 \\
\hline $4 / 19 / 72$ & $0845-1547$ & Sampling & Point & $\$ 1$ & .2 \\
\hline$"$ & $0847-1549$ & " & $"$ & 2 & .2 \\
\hline$"$ & $0900-1550$ & $"$ & $"$ & 3 & .1 \\
\hline$"$ & $0859-1551$ & $"$ & $"$ & 4 & .1 \\
\hline$"$. & $0857-1553$ & $"$ & $"$ & 5 & .0 \\
\hline$"$ & $0856-1555$ & $"$ &.$"$ & 6 & .0 \\
\hline$"$ & $0854-1556$ & $"$ & $"$ & 7 & .4 \\
\hline$"$ & $0853-1557$ & $"$ & $"$ & 8 & .7 \\
\hline$"$ & $0850-1558$ & $"$ & $"$ & 9 & .8 \\
\hline$"$ & $0850-1600$ & $"$ & $"$ & 10 & .1 \\
\hline
\end{tabular}

The 1971 Threshold Limit Value for Carbon black is $3.5 \mathrm{mg} / \mathrm{m}^{3}$. The 1971 Threshold Limit Value for a nuisance dust is $10.0 \mathrm{mg} / \mathrm{m}^{3}$. 


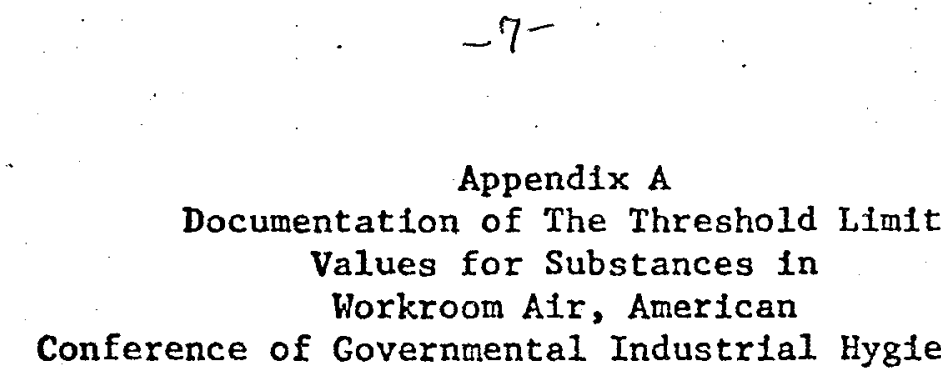

Third Edition, 1971

CARBON BLACK

$3.5 \mathrm{mg} / \mathrm{m}^{3}$

Nau and co-workers(1) conducted extensive carbon black inhalation studies with animals. A channel black and a furnace carbon black, the most widely used types of carbon blacks, were used in the study. The channel black had 1ittle, if any, adsorbed material removable by hot benzene extraction, while the benzene-extractible content of the furnace black was 0.28 percent. Hamsters, mice, guinea pigs, rabbits, and monkeys were exposed for prolonged periods of time, seven hours per day, five days a week, to dust concentrations of either $2.4 \mathrm{mg}$ of channel black per cubic meter of air or $1.6 \mathrm{mg}$ of furnace black per cubic meter. These concentrations were considered to be consistent with the average dustiness in carbon black plants on an average day. No malignancies were observed in any of the exposed antmals. Some evidence of electrocardiographic changes, suggesting right atrial and right ventricular strain, were observed in monkeys after 1,000-1,500 hours of exposure to the channel carbon black. These changes Increased progressively until, after 10,000 hours of exposure the changes were quite marked. With the furnace carbon black the electrocardiographic changes were first observed in monkeys after 2,500 hours of exposure, and marked right atrial and right ventricular strain was noted after 10,000 hours of exposure. The authors concluded that other than the accumulation of dust in the pulmonary system, the prolonged exposure to carbion black produced no significant effects.

Ingalls and Risquez-Iribarren(2) studied the mortality and morbidity experience from all forms of cancer covering a pertod of $17 \frac{1}{2}$ years (1939-1956) of the employees of one of the largest producers of carbon black in this country. It was concluded that the incidence of cancer and the death rate from cancer were low as judged by rates observed among other comparable populations.

VonHaam and Mallette(3) found that some fractions of oily material extracted from carbon black, as obtained by chromatographic separation, were carcinogenic but the unfractionated extracts were not. Later studies made by VonHaam and associates(4) indicated that the activity of some carcinogens was Inhibited by carbon black. 
On the basis of air tests made in rubber plants in Uruguay and in the United Sitates, Sands and Benttez(5) suggested a tentative standard of $3.5 \mathrm{mg}$ of carbon black per cubic meter of alr as a safe and practical goal from the standpoint of rubber mill room dust exposures. They stated that standard dust-counting techniques were not applicable because of the extermely small sizes of carbon black particles. The majority of the rubber reinforcing channel blacks are reported to have particle diameters of 250 to $350 \mathrm{~A}(25$ to $35 \mathrm{millimicrons})(6)$.

\section{References:}

1. Nau, C.A., Neal, J., Stembridge, V.A., Cooley, R.N.: Arch. Environ. Health 4,415 (1962).

2. Ingalls, T.H., Risquez-Iribarren, R.: Arch. Environ. Health 2, 429 (1961).

3. VonHaam, E., Mallette, F.S.: Arch. Ind. Hyg. \& Occup. Med. 6, 237 (1952).

4. VonHaam, E., Titus, H.L., Caplan, I., Shinowara, G.Y.: Proc. Soc. Exper. Bio1. Med. 98, 95 (1958).

5. Sands, F.W., Benitez, J.C.: Proc. 13th Int'l. Cong. on Occup. Health, p. 531, N.Y. (July 1960).

6. Encyclopedia of Chemfcal Technology, Kirk, R.E., Othmer, D.F., Eds., Vol. 3, p. 47, Interscience, N.Y. (1949). 